\title{
NEW SPECIES AND RECORDS OF \\ NORTH AMERICAN PITYOPHTHORUS (COLEOPTERA: SCOLYTIDAE), PART IV: THE SCRIPTOR GROUP
}

\author{
D. E. Bright ${ }^{1}$
}

ABSTRACT- - Six new species of Pityophthorus from Mexico are described. The new species, all in the Scriptor group, are: atkinsoni, diminutivus, equihuai, thamnus, trunculus and zexmenivora. An additional locality record for $P$. coronarius Blackman is included. A new key to the 22 species included in the Scriptor group is presented.

Recently, Dr. T. H. Atkinson (Colegio de Postgraduados, Centro de Entomologia Y Acarologia, Chapingo, Mexico) sent a large collection of Pityophthorus collected by himself and his students to me for identification. A number of samples were collected from plants not previously known to harbor scolytids and are thus a rich source of previously unknown and unsuspected host relationships. A preliminary count indicated that almost 23 undescribed species were included in the collection.

Rather than simply describe and name the new species, I have segregated them into species groups as used in my recent monograph of the genus (Bright, 1981, Mem. Ent. Soc. Canada 118). The species in each group will be described separately, and a new key will be presented where appropriate. The present contribution is the first and includes those species in the Scriptor group. Consult my recent monograph for group diagnoses, for keys to species groups, and for other information.

I thank Dr. T. H. Atkinson for sending the specimens and my colleagues Dr. Y. Bousquet and Dr. J. R. Vockeroth for reading the initial draft of this manuscript.

\section{Pityophthorus atkinsoni, n. sp.}

Length 1.9-2.2 mm, 3.0 times longer than wide.

FEMALE. - Frons flattened on a semicircular area extending from epistoma to well above upper level of eyes, flattened area occu- pying about $66 \%$ of distance between eyes, surface of flattened area densely and finely punctured with dense yellowish setae, these longer and incurved on periphery and along epistoma, surface above and lateral to flattened area shining with large, sparse punctures. Antennal club 1.25 times longer than wide, widest through segment 2; first two sutures straight; first two segments occupy almost $\frac{2}{3}$ of total club length. Pronotum 1.2 times longer than wide, widest at level of summit; sides evenly, moderately arcuate; asperities on anterior slope arranged into two to four evenly concentric rows, if two then two additional rows irregularly arcuate, usually one or two additional broken rows at summit; summit distinctly elevated; posterior area of disc with deep, moderate punctures, these separated by distance equal to or less than their diameters, decreasing in size and more widely separated laterally; surface between punctures shining, with numerous fine impressed points; median line evident, flat, impunctate, with fine impressed points. Elytra 1.9 times longer than wide; apex slightly acuminate; discal striae punctured in even rows, punctures definitely larger than those on posterior portion of pronotal disc, deeply impressed, close, decreasing slightly in size posteriorly, each puncture bearing a very short seta; discal interstriae narrower than striae, surface shining, minutely sculptured with impressed points and lines or reticulate and glabrous. Declivity steep, weakly bisulcate; interstriae 1 moderately elevated, very slightly higher than interstriae 3 , with a me-

${ }^{1}$ Biosystematics Research Institute, Agriculture Canada, Ottawa, Ontario, Canada K1A 0C6. 
dian row of four or five small rounded granules; interstriae 2 very slightly impressed, surface moderately shining, minutely reticulate, slightly wider than interstriae 1 or 3 ; interstriae 3 weakly elevated, lower than 1 , with a median row of five or six small rounded granules; punctures in striae 1 weakly visible, those in striae 2 obsolete.

MALE.-Frons deeply, transversely impressed from epistoma to upper eye level, margins of impressed area sharply defined, especially medianly, surface of impressed area with large, close punctures, a very weakly elevated, longitudinal, impunctate line may be visible, surface above and lateral to impressed area deeply and closely punctured. Pronotum and elytra essentially as in female. Declivity as in female except granules may be slightly larger and punctures in striae 2 may be weakly visible.

TyPe Material. - The holotype $(q)$ bears the labels: "Cardonal (cerca Ixmiquilpan), Edo. Hgo. 27.III.81, 2250 msnm, S-209, col. T. H. Atkinson”/“Hosp.: Compositae”/ "HOLOTYPE Pityophthorus atkinsoni D. E. Bright, 1985." The allotype and four paratypes bear the same labels plus appropriate type labels. Twenty-eight paratypes bear the same labels plus the host label "Hosp. Flourencia resinosa."

The holotype, allotype, and 10 paratypes are in the Canadian National Collection of Insects, Ottawa (CNC No. 18402). Twenty paratypes were returned to Dr. Atkinson, and 2 paratypes were sent to S. L. Wood, Brigham Young University, Provo, Utah.

Comments. - This species does not appear to be related or similar to any species presently placed in the Scriptor group. Adults differ from those of all other species in the group by the combination of the slightly acuminate elytral apex, by the deeply, transversely impressed male frons, by the weakly bisulcate elytral declivity, by the large strial punctures, and by the characters of the female frons.

This species is named after its collector, Dr. T. H. Atkinson, who has collected many new species of Scolytidae in Mexico.

\section{Pityophthorus diminutivus, n. sp.}

Length 0.9-1.0 mm, 3.0 times longer than wide.
Female. - Frons deeply concave from epistoma to well above upper level of eyes, concavity more strongly impressed just above epistoma; surface of concave area brightly shining, with very fine points, or less shining, with fine microreticulation, periphery of concavity with closely placed, long, yellowish setae, those on vertex of concavity reaching about midway to epistoma. Antennal club oval, about 1.3-1.4 times longer than wide, widest near middle; only one suture visible, straight, located just below middle; anterior face glabrous, shining. Pronotum about 1.2 times longer than wide, widest at middle; side straight, parallel; asperities on anterior slope arranged into three definite concentric rows, a vague fourth row detectable at summit; posterior area of disc shining and densely, minutely reticulate, punctures widely separated, very obscure, shallow, barely apparent; median line very vague, faint, impunctate, shallowly impressed. Elytra 2.0 times longer than wide; apex distinctly acuminate; striae punctured in regular rows, punctures large, close, each with an extremely short seta; interstriae about half as wide as striae, impunctate. Declivity steep, generally flattened, bisulcate; interstriae 1 distinctly elevated above 2 , impressed on upper portions slightly below level of interstriae 3 , bearing a median row of very small acute granules; interstriae 2 impressed, widened toward apex, surface glabrous, shining, smooth; interstriae 3 slightly elevated, about as high as 1 on lower half, armed with median row of distinct but small acute granules, these larger than those on interstriae 1 ; punctures in striae 1 and 2 generally distinct, only slightly smaller than those on disc; vestiture of very fine, hairlike setae.

MALE. - Frons very slightly flattened or shallowly, transversely impressed from epistoma to upper level of eyes, upper margin marked by a weak transverse carina; surface with scattered fine setae. Pronotum as in female except asperities in more even, clearly defined concentric rows. Elytra as in female except vestiture on base and face of declivity distinctly broader and scalelike. Declivity essentially as in female except interstriae 1 slightly more deeply impressed below interstriae 3, granules slightly larger; granules on interstriae 3 distinctly larger, arranged near 
middle of declivital face; apical and lateral margins more definitely acute, subtuberculate, extending from interstriae 3 around apex to opposite interstriae 3 ; punctures in striae 1 and 2 obscure.

Type Material. - The holotype $(q)$ is labeled "Estacion de Biologia, Chamela, Edo. Jalisco, 19-VIII-82, S-761, 110 msnm, Col. Armando Equihua"/“Host.: Leguminosae"/ "HOLOTYPE Pityophthorus diminutivus D. E. Bright, 1985." The allotype and nine paratypes bear the same labels plus the appropriate type labels.

The holotype, allotype, and four paratypes are in the Canadian National Collection of Insects, Ottawa (CNC No. 18403). Five paratypes were returned to Dr. Atkinson.

Comments. - This very small species seems to be most closely related to $P$. $h y$ locuroides and related species but differs by the less deeply impressed declivital interstriae 1 , by the very different female frons, and by the much smaller size.

\section{Pityophthorus equihuai, n. sp.}

Length 1.4-1.8 mm, 2.6 times longer than wide.

FEMALE. - Frons broadly flattened from epistoma to well above upper level of eyes and laterally nearly from eye to eye; surface shining and densely pubescent over entire area, setae on periphery much longer, very densely placed, setae arising on upper margin reaching to or beyond epistoma. Antennal club narrowly oval, 1.3 times longer than wide, widest through segment 2 ; sutures 1 and 2 straight, transverse; first two segments occupy more than half of total club length. Pronotum about 1.2-1.3 times longer than wide, widest at level of summit; asperities on anterior slope arranged into four somewhat irregular concentric rows, these more even and regular on lateral areas, with one or two irregular rows around summit; summit weakly elevated; posterior area of disc with shallow, small, illdefined punctures, these widely separated by a distance greater than their diameter; surface between punctures weakly shining, very finely reticulate; median line distinct, narrow, shallowly impressed, impunctate. Elytra 1.6 times longer than wide; apex distinctly acuminate; discal striae punctured in uneven regu- lar rows, punctures larger and deeper than those on posterior portion of pronotum, very close, more irregularly placed on base, each with a very short seta; discal interstriae narrower than striae, surface more brightly shining than surface of pronotum, smooth, with scattered minute points, glabrous. Declivity moderately deeply bisulcate; interstriae 1 distinctly elevated, slightly lower than interstriae 3 on upper portions, with a distinct row of five to seven small rounded granules; interstriae 2 distinctly, moderately impressed, slightly widened on apical half, surface smooth, shining, or moderately dull, with numerous very fine points or very fine reticulate; interstriae 3 convex, moderately elevated, slightly higher than interstriae 1 on upper portions, bearing a median row of three to five distinct rounded granules, these slightly larger than those on interstriae 1; several very small granules present lateral to interstriae 3 on apex of interstriae 4-8; punctures in striae 1 and 2 small, weakly impressed but readily visible, especially in striae 2.

MALE. - Frons shallowly, transversely impressed from epistoma to well above upper level of eyes, surface of impressed area shining, densely, finely punctured with numerous, erect, short setae, surface above and lateral to impressed area more deeply, sparsely punctured, glabrous, shining. Pronotum as in female except asperities on anterior slope larger, in more even concentric rows. Elytra as in female except strial punctures larger, more deeply impressed, declivity more deeply bisulcate, interstriae 1 distinctly lower than interstriae 3 and granules on interstriae 1 and 3 much larger, acute.

Type material. - The holotype $(q)$ is labeled: "Est. de Biologia Chamela, Edo. de Jalisco, S-832, 12-XI-82, 100 m, col. Armando Equihua M"/"HOLOTYPE Pityophthorus equihuai D. E. Bright, 1985.” The allotype and 18 paratypes bear the same label plus an appropriate type label.

The holotype, allotype, and eight paratypes are in the Canadian National Collection of Insects, Ottawa (CNC No. 18404). Eight paratypes were returned to Dr. Atkinson and two paratypes were sent to S. L. Wood, Brigham Young University, Provo, Utah.

Comments. - Adults of this species are similar to those of $P$. mexicanus, coronarius, 
and vesculus but differ in a number of significant characteristics as mentioned in the key.

This species is named after its collector, Armando Equihua, who has collected many undescribed species of Scolytidae in recent years.

\section{Pityophthorus thamnus, n. sp.}

Length $1.9-2.1 \mathrm{~mm}, 3.0$ times longer than wide.

FEMALE. - Frons flattened on large area extending from epistomal margin to upper level of eyes, laterally occupying about $86 \%$ of distance between eyes; surface densely, finely punctate, bearing dense, short, erect setae, all of about equal length. Antennal club oval, 1.3 times longer than wide, widest at middle through segment 2 ; sutures 1 and 2 transverse; segments 1 and 2 together occupy more than half of total club length. Pronotum very slightly longer than wide, widest at middle; sides weakly arcuate, very weakly constricted before anterior margin; asperities on anterior slope arranged into four concentric rows, with one or two small, vague additional rows at summit; summit weakly elevated; posterior portion of disc with moderate size punctures, these widely separated by a distance greater than their diameter; surface between punctures moderately shining, densely, finely, minutely reticulate-punctate; median line weakly elevated behind summit, broad, impunctate toward base. Elytra 2.0 times longer than wide; apex moderately acuminate; discal striae punctured in regular rows, punctures very slightly larger than those on posterior portion of pronotal disc, moderately impressed; discal interstriae about as wide as striae, smooth, moderately shining, minutely reticulate. Declivity sloping, moderately deeply bisulcate; interstriae 1 distinctly elevated, impressed below level of 3 on upper portion, with a few fine granules on basal area and toward apex, central portion devoid of granules; interstriae 2 moderately deeply impressed, widened toward apex, surface smooth, minutely reticulate; interstriae 3 distinctly, moderately elevated, higher than 1 on upper portions, bearing a median row of fine large granules, each bearing an erect seta; puncture in striae 1 and 2 obsolete; if visible, then much smaller, shallower than those on disc.
MALE. - Frons flattened on an area equal to female, weakly, transversely impressed above epistoma; surface with coarse rather large punctures, lower median area just above epistoma weakly, longitudinally elevated, impunctate; vestiture sparse. Pronotum and elytra essentially as in female except punctures, asperities etc. coarser. Declivity as in female except interstriae 3 more strongly elevated above interstriae 1, granules larger; interstriae 1 more deeply impressed and strial punctures slightly larger.

Type Material. - The holotype $(q)$ is labeled: "Pachuca Edo. de Hidalgo, S-462, 21.V.82, 2400 m., col. A. Equihua M.”/ "Zaluzania angusta (Lag.) Sch. Bip. (Compositae)"/"HOLOTYPE Pityophthorus thamnus D. E. Bright, 1985." The allotype and two paratypes bear the same data and appropriate type labels.

The holotype, allotype, and two paratypes are in the Canadian National Collection of Insects, Ottawa (CNC No. 18405). Four paratypes were returned to Dr. Atkinson.

Comments. - Adults of this species are similar to those of $P$. coronarius and related species but differ by the more gradually sloping elytral declivity, by the smaller granules on declivital interstriae 3 , by the less strongly acuminate elytral apex, and by the female frons that bears setae all equal in length.

\section{Pityophthorus trunculus, n. sp.}

Length $1.0 \mathrm{~mm}, 3.0$ times longer than wide.

FEMALE. - Frons broadly flattened on a semicircular area extending from epistoma to slightly above upper eye level and laterally occupying about $65 \%$ of distance between eyes; surface of flattened area densely, finely punctured, a minute tubercule evident just above epistomal margin in some specimens; vestiture short, moderately abundant, generally of equal length, slightly longer on periphery. Antennal club oval, about 1.2 times longer than wide, widest through segment 2 ; first two sutures straight, first two segments occupy slightly more than half of total club length. Pronotum less than 1.1 times longer than wide, widest on posterior half; sides moderately arcuate; asperities on anterior slope arranged into three concentric rows, a 
vague fourth row detectable at summit; posterior area of disc distinctly to weakly shining, punctures entirely obscure, only very weakly indicated; median line not obvious. Elytra 2.0 times longer than wide; apex distinctly acuminate; discal surface completely, minutely reticulate, strial punctures not visible, or at most very weakly indicated. Declivity convex, sloping; interstriae 1 weakly elevated, devoid of granules; interstriae 2 weakly impressed, not sulcate; interstriae 3 not elevated or only weakly so, equal or very slightly higher than 1, with a median row of extremely fine granules; punctures in striae 1 and 2 obsolete. Vestiture sparse, consisting of fine, hairlike setae on declivital interstriae $1,3,5$, etc., those on interstriae 1 much shorter.

MALE.-Frons weakly transversely impressed from epistoma to above upper level of eyes, upper margin of impression slightly more evidently elevated into a short, transverse carina; surface finely, densely punctured. Pronotum and elytra as on female except granules on declivital interstriae 3 very slightly larger.

TyPE MATERIAL. - The holotype $(q)$ bears the labels: "Est. de Biologia Chamela, Edo. de Jalisco, S-831, 12-XI-81, 100 m, col. Armando Equihua M.”" HOLOTYPE Pityophthorus trunculus D. E. Bright, 1985." The allotype and seven paratypes bear the same data plus appropriate type labels.

The holotype, allotype, and two paratypes are in the Canadian National Collection of Insects, Ottawa (CNC No. 18406). Five paratypes were returned to Dr. Atkinson.

Comments. - This species will key to $P$. dimidiatus Blackman or to $P$. minutalis in my 1982 key. Adults of $P$. trunculus differ from those of both species by the entirely impunctate, reticulate elytra (faint strial punctures visible in some specimens), by the nearly impunctate posterior area of the pronotum, and by the smaller size.

\section{Pityophthorus zexmenivora, $\mathrm{n}$. $\mathrm{sp}$.}

Length $1.8 \mathrm{~mm}, 2.7$ times longer than wide.

MALE. - Frons broadly flattened from epistoma to slightly above upper eye level, very weakly transversely impressed above epistoma; surface with coarse, dense, moderate-size punctures, these distinctly impressed, each bearing a short, yellowish, semirecumbent seta. Antennal club oval, about 1.6 times longer than wide, widest through segment 2 ; sutures 1 and 2 transverse; segments 1 and 2 occupy more than half of total club length. Pronotum as long as wide, widest on posterior half; sides subparallel on basal half, weakly but distinctly constricted before anterior margin; asperities on anterior slope arranged into four concentric rows with one or two indistinct rows at summit; summit very weakly elevated; posterior area of disc with coarse moderate size, distinctly impressed punctures, these separated by a distance equal to their diameter; surface between punctures moderately shining, with minute lines and points. Elytra 1.8 times longer than wide; apex strongly acuminate; discal striae punctured in regular rows, punctures equal to or slightly larger than those on posterior portion of pronotum, moderately deep; discal interstriae about as wide or slightly wider than striae, surface smooth, moderately shining, very finely reticulate, impunctate, except near declivity. Declivity sloping, strongly sulcate; interstriae 1 slightly elevated, bearing a few acute granules on base and 1 or 2 large granules at apex; interstriae 2 deeply impressed, broadened toward apex, surface smooth, very minutely reticulate; interstriae 3 strongly elevated, much higher than 1 on upper two-thirds, bearing a median row of large acute granules and long, hairlike setae; punctures of striae 1 and 2 obsolete.

TYPE MATERIAL - The holotype $(\hat{\sigma})$ is labeled "Pachuca, Edo. de Hidalgo, S-461, 21.VI.82, $2400 \mathrm{~m}$, Armando Equihua”/ "Zexmenia sp. (Compositae)"/“HOLOTYPE Pityophthorus zexmenivora D. E. Bright, 1985." One paratype bears the same data with an appropriate type label.

The holotype is in the Canadian National Collection of Insects, Ottawa (CNC No. 18407). The paratype was returned to Dr. Atkinson.

Comments - Adults of $P$. zexmenivora are similar to those of $P$. mexicanus but differ by the lack of a fine, elevated median line on the posterior portion of the pronotum, by the finer, shallower punctures on the pronotum, and by the impunctate elytral interstriae. Adults also key out near P. equihuai but differ 
by the size, by the characters of the declivity, and by other characters given in the key.

Pityophthorus coronarius Blackman Pityophthorus coronarius Blackman, 1942, Proc. U.S. Nat. Mus. 92: 220; Bright, 1981, Mem. Ent. Soc. Canada 118: 33; Wood, 1982, Great Basin Nat. Mem. 6:1115.
This species was previously known from Jalisco, Mexico, from Sambucus sp. A series of eight specimens are labeled: "Rancho Tetela, Cuernavaca, Mor.[elos], Compositae, 10 Enero 1982, $1750 \mathrm{~m}$, Col. BUSA-SACEMAFE.”

\section{Key to species in Scriptor group \\ (Modified from Bright 1981)}

1. Interstriae 1 moderately to strongly impressed below level of interstriae 3 on upper declivity (especially in males); granules on declivital interstriae 3 usually

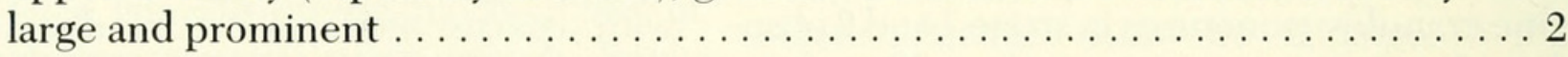

Interstriae 1 not impressed on declivity or only weakly impressed, equal in height to interstriae 3, or at most very slightly lower; granules on interstriae 3 usually very small

2(1). Declivital sulcus very wide, flattened to interstriae 5, interstriae 1 only slightly lower than 3 on upper half; male frons strongly, transversely impressed from epistoma to upper level of eyes; posterior portion of pronotum obscurely punctured, reticulate; body slender, about 3.1 times longer than wide;

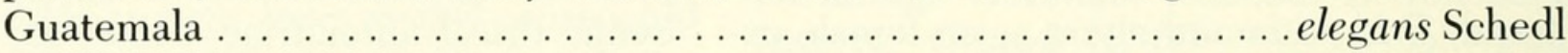

Declivital sulcus more convex, more deeply bisulcate; male frons variable; posterior portion of pronotum distinctly punctured $\ldots \ldots \ldots \ldots \ldots \ldots \ldots$

3(2). On conifers in SW United States; declivital interstriae 2 very broad, moderately sulcate; pronotal asperities arranged in even or irregular rows; female frons pubescent over entire surface, setae on periphery longer and incurved . . . . . .

arcanus Bright

On shrubs in SE and W United States or in deciduous trees or shrubs in Central America; declivital interstriae 2 not broadly sulcate; pronotal asperities scattered or in even concentric rows; female frons variable but not as above $\ldots \ldots \ldots \ldots \ldots 4$

4(3). Pronotal asperities numerous, confused, in no apparent order; declivital striae 1 and 2 with distinct punctures, these almost equal in size to those on disc; declivital setae of male narrowly spatulate; Panama . . . . . . . . vesculus Wood Pronotal asperities arranged in even concentric rows; punctures in declivital

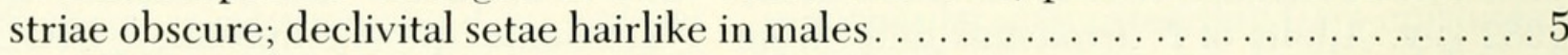

5(4). Larger species; male frons convex, without a carina; declivity more gradual, apex strongly acuminate, interstriae 3 armed by median row of distinct granules,

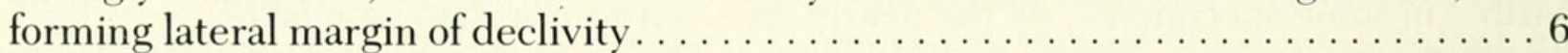

Small species; male frons transversely impressed, with a distinct, transverse carina at upper level of eyes; declivity steeper, apex moderately to weakly acuminate; interstriae 3 granulate to middle of declivital face, not forming lateral

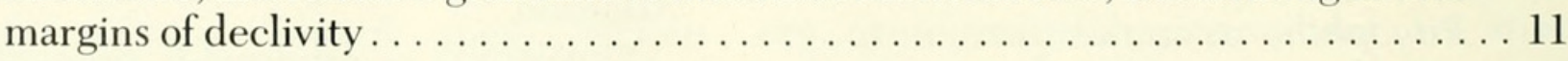

6(5). Declivity sloping, beginning on posterior one-fourth of elytra, moderately impressed, granules on interstriae 3 small; elytral apex moderately acuminate; female frons with short setae, all equal in length; Mexico . . . . . . . thamnus Bright

Declivity steep, beginning on posterior third of elytra, usually strongly impressed, granules on interstriae 3 large; elytral apex moderately to strongly acuminate; female frons with long setae, especially on periphery $\ldots \ldots \ldots \ldots \ldots$ 
7(6). Posterior portion of pronotum bearing rounded, elevated granules on lateral or posterior edges of punctures; surface between punctures on posterior portion of pronotum strongly and densely reticulate; female frons densely pubescent, with longer, downward-pointing setae on upper and lateral margin

- Posterior portion of pronotum not bearing rounded, elevated granules on edges of punctures; surface between punctures on posterior portion of pronotum not strongly reticulate, or punctures obsolete; females frons variable

8(7). Body slender, about 2.9-3.0 times longer than wide; female frons broadly flattened, densely pubescent with long setae on upper and lateral margins; male frons flattened; interstriae 1 on declivity with small granules along entire length, granules on interstriae 3 slightly larger; Mexico. coronarius Blackman

Body stouter, 2.7-2.8 times longer than wide; female frons broadly concave, with long setae on complete periphery; male frons moderately, transversely impressed; interstriae 1 on declivity devoid of granules except at base and at apex, granules on interstriae 3 acute, prominent; Mexico......... concinnus Wood

9(7). Median line on posterior portion of pronotum sharply, narrowly elevated; punctures on posterior portion of pronotum large, deep, almost touching; discal interstriae $1,3,5,7$ usually with a median row of sparse setae extending nearly to base; Mexico ........................... mexicanus Blackman Median line on pronotum not elevated; punctures on posterior portion of pronotum finer, shallower, and more widely separated; discal interstriae usually impunctate.

10(9). Body length $1.8 \mathrm{~mm}$; declivity deeply sulcate, interstriae 3 strongly elevated, inner slope abrupt; median portion declivital interstriae 1 devoid of granules; Mexico . . . zexmenivora Bright

Body length 1.4-1.8 mm; declivity weakly sulcate, interstriae 3 only slightly higher than 1 , granules on interstriae 1 and 3 very large; setae on female frons very long, extending from vertex to epistoma; Mexico equihuai Bright

11(5). Length 0.9-1.0 $\mathrm{mm}$; female frons concavely impressed, shining, glabrous in center, periphery with long, yellowish setae; punctures on posterior portion of pronotum obsolete, surface between punctures reticulate; Mexico.

diminutivus Bright

Length greater than $1.2 \mathrm{~mm}$; female frons flattened, densely pubescent over entire surface; punctures on posterior portion of pronotum distinct, surface between punctures smooth

12(11). Declivity deeply sulcate in male, moderately sulcate in female, interstriae 3 much higher than 1 on declivital base, with large coarse granules; interstriae 2 distinctly broadened toward apex in male, punctures in striae 2 obscure in male, distinct in female

Declivity shallowly sulcate, interstriae 3 moderately or only slightly higher than 1 , with moderately large or small granules; interstriae 2 variable, but not broadened toward apex in male, punctures in striae 2 distinct in both sexes . . . 14

13(12). Declivity of male very steep, flattened, with an acute, tuberculate margin extending from top of interstriae 3 around apex to opposite interstriae 3 , granules on interstriae 1 and 3 large, acute; declivity of female convex, less deeply sulcate, with prominent granules on interstriae 1 and 3; central Mexico... hylocuroides Wood Declivity of male less steep, obscurely flattened on lower half, lateral margin lateral to interstriae 3 rounded, granules on interstriae 1 small to absent, on interstriae 3 slightly larger, acute; declivity of female more convex, less deeply sulcate, with small granules on interstriae 1 and 3; Idaho to northern Mexico and west Texas 
14(12). Granules on declivital interstriae 1 and 3 small; female frons evenly pubescent on a large semicircular area, setae slightly longer on periphery; male frons moderately deeply, transversely impressed; southeastern USA . . scriptor Blackman Granules on declivital interstriae 1 and 3 moderately large; female frons densely pubescent, the setae on the periphery very closely placed and very long, extending downward almost to epistoma and masking surface of frons; male frons shallowly, transversely impressed; Honduras . . . . . . . . . hermosus Wood

15(1). Declivity distinctly flattened, very weakly sulcate, interstriae 1 and 3 very weakly elevated with fine granules; male frons distinctly, transversely impressed, impression deeply punctured; female frons densely, evenly pubescent;

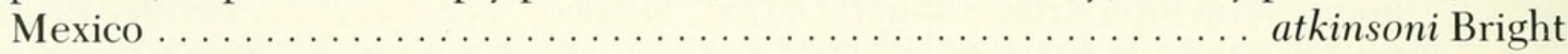

Declivity variable but distinctly convex and bisulcate; male frons flattened or weakly, transversely impressed; female frons variable

16(15). Basal half of pronotum dull, minutely reticulate, punctures barely visible, if at

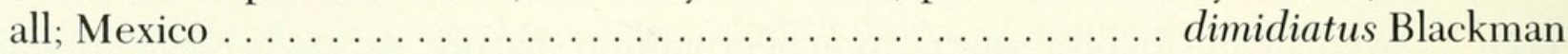
Basal half of pronotum dull to shining, smooth, punctures usually distinctly

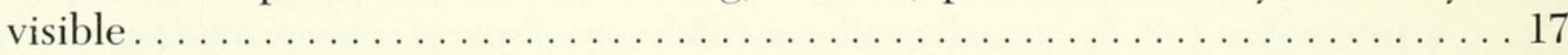

17(16). Punctures in declivital striae 2 obscure, difficult if not impossible to see . . . . . 18 Punctures in declivital striae 2 distinct, obvious $\ldots \ldots \ldots \ldots \ldots \ldots \ldots \ldots$

18(17). Declivital interstriae 1 and 3 devoid of granules or granules extremely minute . . . 19 Declivital interstriae 1 and 3 with generally distinct granules . . . . . . . 20

19(18). Elytral strial punctures obsolete, entire surface minutely reticulate; punctures on posterior surface of pronotum obsolete; female frons flattened, with abundant setae of equal length over surface; length $1.0 \mathrm{~mm}$; Mexico . . . . . . trunculus Bright Elytral strial punctures distinct, in even rows, entire surface smooth; punctures on posterior surface of pronotum distinct; female frons flattened, pubescence long on periphery, somewhat sparser on a median longitudinal space; length

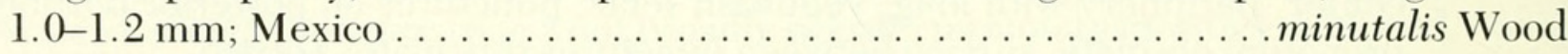

20(18). Male frons convex, with a weak longitudinal carina; female frons concave, uniformly covered with dense pubescence, setae on periphery longer and in-

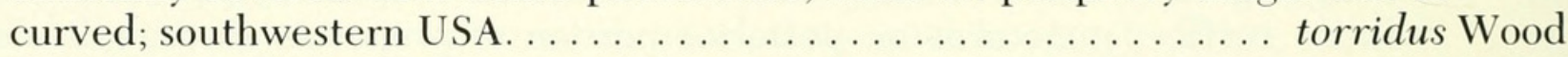

Male frons very weakly, transversely impressed, with an extremely fine, longitudinal carina or a narrow, longitudinal, smooth space; female frons flattened, with either three tufts of extremely long, fine setae extending downward to apex of mandibles or with flattened area uniformly pubescent

21(20). Female frons with three tufts of extremely long, downward-pointing setae that extend almost to tips of mandibles; male frons generally convex, narrowly, transversely impressed above epistoma, with a weak longitudinal carina;

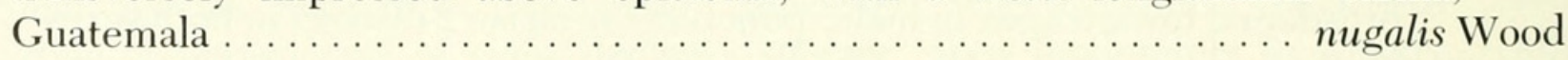

Female frons uniformly pubescent on a subcircular area occupying $70 \%-75 \%$ of distance between eyes, setae short, usually all of equal length; male frons weakly, transversely impressed from epistoma to upper level of eye, usually with a longitudinal smooth space; Mexico.

22(21). Size smaller, $0.8-1.2 \mathrm{~mm}$; declivital interstriae 2 very weakly impressed, interstriae 3 weakly elevated, granules on 1 and 3 minute, obscure . . atomus Wood Size larger, 1.2-1.5 mm; declivital interstriae 2 more deeply impressed, interstriae 3 distinctly elevated, granules on 1 and 3 distinct . . attenuatus Blackman 
23(17). On Pinus spp.; surface between punctures on posterior portion of pronotum

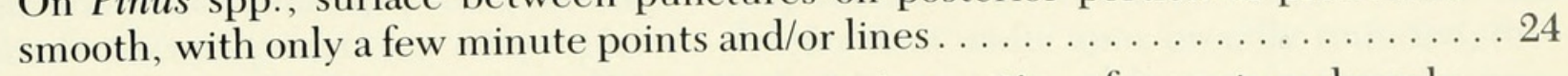
On vines; surface between punctures on posterior portion of pronotum densely micropunctate; Costa Rica .......................... sobrinus Wood

24(23). Elytral apex distinctly, strongly acuminate, apices projecting downward on female; southern Mexico and Guatemala (see Confertus group).... subsimilis Schedl Elytral apex moderately acuminate, apices not projecting downward on female; southern Mexico (see Confertus group) . . . . . . . . . . . subimpressus Bright 


\section{$2 \mathrm{BHL}$ Biodiversity Heritage Library}

1985. "New species and records of North American Pityophthorus

(Coleoptera: Scolytidae), part 4: the scriptor group." The Great Basin naturalist 45, 467-475. https://doi.org/10.5962/bhl.part.4434.

View This Item Online: https://www.biodiversitylibrary.org/item/35771

DOI: https://doi.org/10.5962/bhl.part.4434

Permalink: https://www.biodiversitylibrary.org/partpdf/4434

\section{Holding Institution}

Harvard University, Museum of Comparative Zoology, Ernst Mayr Library

\section{Sponsored by}

Harvard University, Museum of Comparative Zoology, Ernst Mayr Library

\section{Copyright \& Reuse}

Copyright Status: In copyright. Digitized with the permission of the rights holder.

License: http://creativecommons.org/licenses/by-nc-sa/3.0/

Rights: https://biodiversitylibrary.org/permissions

This document was created from content at the Biodiversity Heritage Library, the world's largest open access digital library for biodiversity literature and archives. Visit BHL at https://www.biodiversitylibrary.org. 